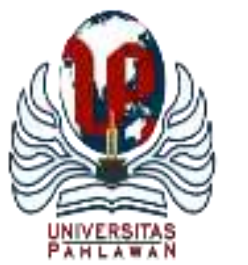

Edukatif : Jurnal Ilmu Pendidikan Volume 3 Nomor 5 Tahun 2021 Halm 3332 - 3338

EDUKATIF: JURNAL ILMU PENDIDIKAN

Research \& Learning in Education

https://edukatif.org/index.php/edukatif/index

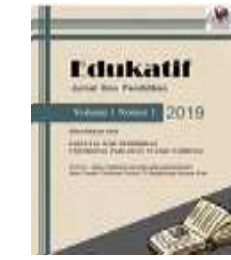

\title{
Pengaruh Penggunaan Video Pembelajaran terhadap Kemampuan Berpikir Siswa pada Mata Pelajaran Kimia
}

\author{
Vina N. Van Harling ${ }^{\square}$ \\ Politeknik Saint Paul Sorong, Indonesia \\ E-mail : nath.vin87@gmail.com
}

\begin{abstract}
Abstrak
Penelitian ini bertujuan untuk melihat pengaruh dari penggunaan video pembelajaran terhadap kemampuan berpikir siswa selama proses belajar dari rumah. Penelitian ini termasuk dalam jenis penelitian Quasi Experimental, dengan sampel kelas XI IPA 1 sebagai kelas kontrol dan kelas XI IPA 2 sebagai kelas eksperimen. Data hasil penelitian kemudian dianalisis dengan menggunakan teknik analisis statistik deskriptif dan statistic inferensial yang diawali dengan pengujian normalitas data dengan mengunakan uji KolmogorovSmirnov dengan menggunakan aplikasi IBM SPSS Statistic 25. Uji prasyarat ini bila menunjukkan data berdistribusi normal maka akan dilakukan pengujian dengan menggunakan statistic parametrik yaitu uji t, sementara bila hasil pengujian prasyarat data yang dihasilkan tidak berdistribusi normal maka pengujian akan menggunakan statistic non parametrik. Hasil pengujian diperoleh hasil sebesar 0,000 yang berarti lebih kecil dari < nilai probabilitas 0,05. Hasil ini menunjukkan bahwa nilai Hi diterima dan Ho ditolak, sehingga dapat dikatakan bahwa tidak ada pengaruh penggunaan video pembelajaran untuk mata pelajaran kimia terhadap kemampuan berpikir siswa.
\end{abstract}

Kata Kunci: kimia, kemampuan berpikir, video pembelajaran, BDR

\begin{abstract}
This study aims to see the effect of using learning videos on students' thinking skills during the learning process from home. This research is included in the type of Quasi-Experimental research, with a sample of class XI IPA 1 as the control class and class XI IPA 2 as the experimental class. The research data were then analyzed using descriptive statistical analysis techniques and inferential statistics which began with testing the normality of the data using the Kolmogorov-Smirnov test using the IBM SPSS Statistic 25 application. This prerequisite test, if the data shows the normal distribution, will be tested using parametric statistics. namely the t-test, while if the results of the prerequisite test results are not normally distributed, the test will use non-parametric statistics. The test results obtained a result of 0.000 which means it is smaller than the $<0.05$ probability value. These results indicate that the value of Hi is accepted and Ho is rejected, so it can be said that there is no effect of using learning videos for chemistry subjects on students' thinking skills.
\end{abstract}

Keywords: chemistry, thinking ability, tutorial video, $B D R$

Copyright (c) 2021 Vina N. Van Harling

$\triangle$ Corresponding author:

Email : nath.vin87@gmail.com

DOI : https://doi.org/10.31004/edukatif.v3i5.1215

ISSN 2656-8063 (Media Cetak)

ISSN 2656-8071 (Media Online)

Edukatif : Jurnal Ilmu Pendidikan Vol 3 No 5 Tahun 2021 p-ISSN 2656-8063 e-ISSN 2656-8071 


\section{Pengaruh Penggunaan Video Pembelajaran terhadap Kemampuan Berpikir Siswa pada Mata Pelajaran Kimia - Vina N. Van Harling \\ DOI: https://doi.org/10.31004/edukatif.v3i5.1215}

\section{PENDAHULUAN}

Hakikatnya pendidikan merupakan suatu upaya untuk mengembangkan potensi siswa yang dikembangkan melalui suatu proses yang kompleks, dan proses tersebut mengalami perubahan mengikuti perkembangan kemajuan teknologi dan informasi. Kemajuan teknologi dan informasi yang sangat pesat saat ini telah dimanfaatkan dengan baik dalam bidang pendidikan, dan pemanfaatan kemajuan ini terlihat jelas disaat pandemic Covid - 19 dimana proses pembelajaran dilaksanakan secara online dari rumah. Pemanfaatan teknologi informasi ini juga dapat dimanfaatkan oleh Sekolah Menengah Atas untuk kemajuan proses pembelajaran selama pandemi. Proses pembelajaran dengan memanfaatkan teknologi saat ini berupa penggunaan Google Classroom, e-learning, moodle dan lain sebagainya. Pemanfaatan aplikasi ini dalam pendidikan memberikan banyak kemudahan, seperti adanya peningkatan dan pengembangan kemampuan professional guru, sebagai alat bantu interaksi dalam pembelajaran.

Berjalannya waktu proses pembelajaran yang memanfaatkan berbagai aplikasi tersebut tidak hanya berupa mengirimkan materi pembelajaran, tugas - tugas, kuis dan absensi saja. Namun melalui aplikasi tersebut guru juga dapat memberikan materi pembelajaran dalam bentuk video pembelajaran. Video pembelajaran merupakan media pembelajaran audio - visual yang digunakan dalam kegiatan pembelajaran dengan melibatkan indera penglihatan dan indera pendengaran dalam proses pembelajaran. (Panggabean. 2021). Lebih lanjut dikemukakan bahwa, materi yang merupakan informasi yang disaluran disampaikan dalam bentuk pesan verbal dan nonverbal yang mengandalkan penglihatan maupun pendengaran. komunikasi dalam hal ini pemberian materi ajar dari guru kepada siswa. Saat ini penggunaan video pembelajaran dianggap dapat menarik minat belajar siswa selama proses belajar dari rumah karena dapat membantu menyelesaikan setiap tahap pembelajaran dan diangap dapat membuat siswa memahami materi dengan lebih baik.

Penggunaan media video dalam proses pembelajaran memberikan manfaat yang sangat besar bagi guru dan siswa seperti: 1). Guru mencapai efektifitas pembelajaran khususnya pada mata pelajaran yang mayoritas praktek; 2). Video pembelajaran dapat memaksimalkan pencapaian tujuan pembelajaran dalam waktu yang singkat; 3). Dapat merangsang minat belajar siswa untuk lebih mandiri; 4). Siswa dapat belajar berkonsentrasi; 5). Daya nalar siswa lebih focus dan lebih kompeten; 6). Siswa menjadi aktif dan termotivasi untuk mempraktekan latihan - latihan, (Panggabean. 2021)

Proses belajar dari rumah yang saat ini dilakukan di SMA Negeri 3 Sorong juga menggunakan berbagai aplikasi yang disediakan oleh pihak sekolah, dan guru harus mampu untuk berimprovisasi dengan berbagai metode ajar yang dapat menumbuhkan minat dan belajar siswa selama proses belajar dari rumah. Salah satunya dalam mata pelajaran kimia di kelas 11 IPA SMA Negeri 3 Sorong. Proses pembelajaran kimia saat ini dilakukan dengan menggunakan media video pembelajaran melalui aplikasi google classroom. Google classrom sendiri merupakan layanan yang dikembangkan oleh google untuk menyederhanakan tugas pengajar saat mendistribusikan tugas dan materi, serta menilai tugas dan ujian peserta didik tanpa menggunakan kertas. (Van Harling. 2021) Proses pembelajaran dengan menggunakan video pembelajaran ini dilakukan berdasarkan hasil evaluasi pelajaran kimia di semester gasal tahun ajaran 2019/2020. Berdasarkan hasil wawancara saat proses belajar dari rumah saat semester gasal, siswa merasa terdapat beberapa materi yang masih sangat sulit dipahami terutama untuk materi perhitungan, walaupun telah dijelaskan saat tatap muka online dengan menggunakan zoom.

Hal yang dialami oleh siswa kelas 11 SMA Negeri 3 Sorong ini, ternyata juga dialami oleh SMA Negeri 1 Gabus, Kabupaten Grobogan. Dimana selama proses pembelajaran dari rumah, siswa perlu adanya pengulangan materi yang didapat dan upayanya adalah siswa bertanya kepada guru ketika tidak dapat memahami materi di bawah pantauan orang tua. (Dewi, 2021) Lebih lanjut dijelaskan bahwa hal ini dilakukan oleh pihak sekolah agar dapat meningkatkan kemampuan berpikir siswa selama proses pembelajaran, dimana siswa yang belum memahami materi yang diajarkan dapat mengulang kembali materi dan contoh soal yang 
dijelaskan, dengan demikian kemampuan berpikir siswa dapat berkembang semakin baik. Hanya saja keterbatasan waktu dan ruang akan dialami oleh guru dan siswa selama proses pemahaman lebih lanjut.

Berdasar hal inilah maka pada saat semester genap proses pembelajaran kimia di kelas XI IPA SMA Negeri 3 Sorong diubah menggunakan model pembelajaran dengan menggunakan media video pembelajaran, Hal ini didukung oleh penelitian yang dilakukan oleh Wahyuningtyas (2020) dalam penelitiannya mengenai Pentingnya Media Dalam Pembelajaran Guna Meningkatkan Hasil Belajar di Sekolah Dasar, dimana ditemukan hasil bahwa penggunaan media saat proses pembelajaran dapat mempermudah siswa memahami materi pelajaran sehingga memperoleh hasil belajar yang memuaskan, selain itu penggunaan media pembelajaran menjadikan siswa tidak terpaku pada guru yang menyajikan materi. Untuk itu dirasakan bahwa dengan adanya model pembelajaran yang menggunakan video untuk materi kimia kelas XI dapat meningkatkan kemampuan berpikir siswa.

Model pembelajaran dengan media pembelajaran berupa video pembelajaran memiliki keunggulan dalam penggunaannya. Daryanto (2018) dalam Novita (2019) menuliskan kelebihan penggunaan video adalah: 1) menambah dimensi baru di dalam proses pembelajaran, karena video menyajikan gambar dan suara kepada siswa. 2) penggunaan video dapat menampilkan fenomena yang sulit dilihat secara nyata. Selain itu keunggunalan menggunakan video pembelajaran menurut Rusman,dkk (2012) dalam Wisada (2019) adalah: 1) dapat memberikan pesan yang dapat diterima secara lebih merata oleh siswa. 2) sangat bagus untuk menerangkan suatu proses, 3) dapat mengatasi keterbatasan ruang dan waktu, 5) lebih realistis karena dapat diulang dan dihentikan sesuai dengan kebutuhan, dan 5) memberikan kesan yang mendalam dalam mempengaruhi sikap siswa. Namun dibalik kelebihan yang ada terdapat kelemahan dari penggunaan video pembelajaran yaitu adanya opposition, kebutuhan akan material pendukung dan juga budget selama proses pembuatan video. (Novita. 2019)

Sebelum penelitian ini dilakukan, telah hadir beberapa penelitian yang menunjukkan pentingnya penggunaan video pembelajaran dalam proses belajar mengajar. Dalam penelitiannya tentang Pengaruh Media Video Pembelajaran Terhadap Hasil Belajar IPA Ditinjau dari Keaktifan Siswa, Yunita (2017) menyatakan bahwa ada pengaruh penggunaan media video pembelajaran terhadap hasil belajar IPA ditinjau dari keaktifan siswa. Penelitian lain mengenai penggunaan video pembelajaran juga dilakukan oleh Syamsidah (2018) melalui penelitian Pengaruh Video Pembelajaran Kimia Terhadap Motivasi dan Hasil Belajar Kimia Siswa Kelas $\mathrm{X}$ yang menunjukkan bahwa ada pengaruh signifikan penggunaan video pembelajaran kimia terhadap motivasi dan tidak ada pengaruh signifikan penggunaan video pembelajaran kimia terhadap hasil belajar siswa pada materi larutan elektrolit dan nonelektrolit. Kedua penelitian yang telah dilakukan ini diterapkan pada saat proses tatap muka berlangsung di ruangan kelas. Namun pada saat ini dengan proses pembelajaran yang dilakukan secara online mengharuskan siswa untuk dapat meningkatkan kemampuan berpikir mereka saat diberikan metode pembelajaran dengan menggunakan media video pembelajaran.

Melihat belum adanya penelitian yang menghubungkan penggunaan video pembelajaran dengan kemampuan berpikir siswa, dan hasil yang akan dicapai selama proses pembelajaran dengan menggunakan video pembelajaran maka penelitian ini bertujuan untuk melihat pengaruh dari penggunaan video pembelajaran terhadap kemampuan berpikir siswa selama proses belajar dari rumah.

\section{METODE PENELITIAN}

Penelitian ini dilaksanakan selama 1 semester di SMA Negeri 3 Sorong. Penelitian ini termasuk dalam jenis penelitian Quasi Experimental yaitu penelitian dimana peneliti tidak melakukan randomisasi dalam penentuan subjek kelompok penelitian, namun hasil penelitian yang diperoleh cukup berarti baik ditinjau dari validitas internal maupun eksternal. (Yusuf. 2017)

Populasi yang diambil dalam penelitian ini adalah siswa/i kelas XI IPA dari 7 kelas, sementara sampel yang digunakan dalam penelitian diambil dari 2 kelas yaitu kelas XI IPA 1 dan XI IPA 2 yang masing - 
3335 Pengaruh Penggunaan Video Pembelajaran terhadap Kemampuan Berpikir Siswa pada Mata Pelajaran Kimia - Vina N. Van Harling

DOI: https://doi.org/10.31004/edukatif.v3i5.1215

masing kelasnya berjumlah 36 siswa/i. Desain penelitian menggunakan 2 kelas yang mana kelas XI IPA 1 dijadikan sebagai kelas kontrol dan kelas XI IPA 2 sebagai kelas eksperiman. Selama penelitian sampel akan diberikan pretest dan posttest untuk melihat sampai sejauh mana kemampuan berpikir siswa sebelum dan sesudah proses pembelajaran dengan menggunakan video pembelajaran.

Data hasil penelitian kemudian dianalisis dengan menggunakan teknik analisis statistik deskriptif dan statistic inferensial yang diawali dengan pengujian normalitas data dengan mengunakan uji KolmogorovSmirnov dengan menggunakan aplikasi IBM SPSS Statistic 25. Uji prasyarat ini bila menunjukkan data berdistribusi normal maka akan dilakukan pengujian dengan menggunakan statistic parametrik yaitu uji $t$, sementara bila hasil pengujian prasyarat data yang dihasilkan tidak berdistribusi normal maka pengujian akan menggunakan statistic non parametrik.

\section{HASIL DAN PEMBAHASAN PENELITIAN}

Data penelitian yang dihasilkan dalam penelitian ini diperoleh dari data hasil post test kelas kontrol dan kelas eksperimen. Dimana kelas kontrol pada saat proses belajar dari rumah siswa diajarkan menggunakan metode konvensional dan tidak diberikan video pembelajaran, sementara untuk kelas eksperimen proses belajar dari rumah dilakukan dengan memberikan video pembelajaran. Hasil analisis statistic deskriptif disajikan dalam table berikut.

Tabel 1

Hasil Analisis Deskriptif Kelas Kontrol dan Kelas Eksperimen

\begin{tabular}{lcccccc}
\hline & $\mathrm{N}$ & Range & Minimum & Maximum & Mean & Std. Deviation \\
\hline $\begin{array}{l}\text { Menggunakan video } \\
\text { pembelajaran }\end{array}$ & 36 & 10 & 80 & 90 & 84.22 & 2.948 \\
$\begin{array}{l}\text { Tidak menggunakan } \\
\text { video pembelajaran }\end{array}$ & 36 & 8 & 76 & 84 & 79.94 & 2.267 \\
\hline Valid N (listwise) & 36 & & & & & \\
\hline
\end{tabular}

Berdasarkan hasil analisis tabel di atas terlihat bahwa rata - rata nilai hasil post test dari kelas eksperimen sebesar 84, 22 dengan nilai minimum 80 dan nilai maksimum post tes adalah 90. Sementara untuk kelas kontrol nilai rata - rata yang diperoleh sebesar 79,94, nilai minimum hasil posttest adalah 76 dan nilai maksimum hasil posttest 84. Hasil ini menunjukkan bahwa kemampuan siswa berpikir siswa dengan menggunakan video pembelajaran berdasarkan hasil posttest lebih tinggi bila dibandingkan dengan kemampuan berpikir siswa yang diajarkan dengan metode konvensional atau tanpa menggunakan video pembelajaran.

Pengujian selanjutnya adalah pengujian normalitas. Pengujian ini perlu dilakukan untuk melihat sebaran data yang dihasilkan terdistribusi normal atau tidak. Pengujian dilakukan dengan menggunakan IBM SPSS Statistic 25. Hasil pengujian kemampuan berpikir siswa disajikan dalam table berikut.

Tabel 2

Hasil Analisis Pengujian Normalitas Kelas Kontrol dan Kelas Eksperimen

\begin{tabular}{lcccccc}
\hline & \multicolumn{3}{c}{ Kolmogorov-Smirnov $^{\mathrm{a}}$} & \multicolumn{3}{c}{ Shapiro-Wilk } \\
\cline { 2 - 7 } & Statistic & df & Sig. & Statistic & df & Sig. \\
\hline $\begin{array}{l}\text { Menggunakan video } \\
\text { pembelajaran }\end{array}$ & .137 & 36 & .087 & .932 & 36 & .029 \\
$\begin{array}{l}\text { Tidak menggunakan } \\
\text { video pembelajaran }\end{array}$ & .193 & 36 & .002 & .911 & 36 & .007 \\
\hline a & & & & & &
\end{tabular}

a. Lilliefors Significance Correction

Dari table 2 di atas terlihat bahwa hasil pengujian normalitas kemampuan berpikir siswa di kelas eksperimen diperoleh nilai signifikansi sebesar 0,087 yang berarti signifikansi $>0,05$. Sementara hasil pengujian normalitas untuk kelas kontrol diperoleh hasil signifikansi sebesar 0,002 yang berarti signifikansi < 
3336 Pengaruh Penggunaan Video Pembelajaran terhadap Kemampuan Berpikir Siswa pada Mata Pelajaran Kimia - Vina N. Van Harling

DOI: https://doi.org/10.31004/edukatif.v3i5.1215

0,05. Hasil pengujian ini menunjukkan bahwa data kemampuan berpikir siswa pada kelas kelas eksperimen terdistribusi normal, sementara pada kelas kontrol tidak terdistribusi dengan normal. Untuk itu pengujian akan menggunakan statistic non parametrik dengan menggunakan uji $U$ Mann Whitney. Hasil pengujian kemampuan berpikir siswa di kelas kontrol dan kelas eksperimen disajikan dalam table 3

Tabel 3

Hasil Pengujian Non Parametrik Mann-Whitney

\begin{tabular}{lr}
\hline \multicolumn{2}{c}{ Test Statistics $^{\mathbf{a}}$} \\
\hline Mann-Whitney U & Posttest \\
\hline Wilcoxon W & 173.000 \\
\hline Z & 839.000 \\
\hline Asymp. Sig. (2-tailed) & -5.424 \\
\hline a. Grouping Variable: Kelas & .000 \\
\hline
\end{tabular}

Hasil pengujian nilai signifikansi ( 2 ekor) diperoleh hasil sebesar 0,000 yang berarti bahwa hasil pengujian < nilai probabilitas 0,05. Hasil ini menunjukkan bahwa nilai Hi diterima dan Ho ditolak, sehingga dapat dikatakan bahwa tidak ada pengaruh penggunaan video pembelajaran untuk mata pelajaran kimia terhadap kemampuan berpikir siswa.

Penelitian ini menunjukkan bahwa penggunaan video pembelajaran tidak berpengaruh terhadap kemampuan berpikir siswa. Hasil ini bertolak belakang dengan hasil penelitian dari Yunita (2017) yang menyatakan bahwa ada pengaruh penggunaan media video pembelajaran terhadap hasil belajar IPA siswa kelas VII SMP Negeri 1 Turi TA 2016/2017 ditinjau dari keaktifan siswa. Hal ini juga sejalan dengan hasil penelitian Syamsidah (2018) dimana dalam penelitiannya menyatakan bahwa video pembelajaran kimia terbukti ampuh untuk mengatasi masalah hasil belajar kimia siswa yang memiliki kemampuan dasar kimia yang rendah. Media video pembelajaran menyajikan gambar, suara serta materi yang diperjelas hingga dapat meningkatkan pemahaman konsep siswa terhadap pembelajaran kimia. Pemahaman konsep akan lebih baik bila adanya sesuatu yang baru yang diberikan bagi siswa.

Bahar (2018) mengemukakan bahwa dalam belajar bermakna pengetahuan baru akan lebih meningkatkan pemahaman konsep yang lebih sehingga siswa akan jauh lebih memahami materi yang diajarkan. Peningkatan pemahaman konsep ini akan sejalan dengan perubahan kemampuan berpikir siswa. Kemampuan berpikir umumnya digunakan untuk memahami konsep, menerapkan, mensintesis, dan mengevaluasi informasi yang didapat atau dihasilkan. (Zubaidah. 2010) Peningkatan kemampuan berpikir dapat terjadi bila dalam proses pembelajaran dengan menggunakan video pembelajaran, guru memberikan berbagai pertanyaan yang dapat membuat siswa untuk melakukan penyelidikan akan permasalahan sehingga akan menumbuhkan kemampuan siswa untuk memecahkan masalah yang ada. Pernyataan ini sejalan dengan penelitian Agnafia (2019) yang menuliskan bahwa pengembangan kemampuan berpikir kritis dilakukan oleh guru dengan jalan melatih kemampuan berpikir kritis dan juga memfasilitasi dalam kegiatan pembelajaran dengan indicator - indicator berpikir kritis.

Namun pada kenyataannya tidak semua siswa mampu untuk berpikiris kritis, karena masih banyak siswa yang masih mengutamakan proses mengingat atau menghafalkan dan memahami materi yang diajarkan oleh guru mereka yang hanya bersumber dari buku dan penjelasan guru walaupun telah diberikan video pembelajaran. Hal ini dikarenakan kemampuan berpikir setiap siswa berbeda - beda, kemampuan merupakan bagian yang fundamental dalam kematangan manusia. (Wahyuni. 2015)

\section{KESIMPULAN}

Kesimpulan yang dapat ditarik dari penelitian Pengaruh Penggunaan Video Pembelajaran Untuk Mata Pelajaran Kimia Terhadap Kemampuan Berpikir Siswa adalah tidak ada pengaruh penggunaan video pembelajaran untuk mata pelajaran kimia terhadap kemampuan berpikir siswa. 
3337 Pengaruh Penggunaan Video Pembelajaran terhadap Kemampuan Berpikir Siswa pada Mata Pelajaran Kimia - Vina N. Van Harling

DOI: https://doi.org/10.31004/edukatif.v3i5.1215

\section{DAFTAR PUSTAKA}

Agnafia, D. N. (2019). Analisis kemampuan berpikir kritis siswa dalam pembelajaran Biologi. Florea: Jurnal Biologi dan Pembelajarannya, 6(1), 45-53.

Bahar, H., \& Salempa, P. (2018). Pengaruh Penggunaan Video Praktikum pada Pembelajaran Inkuiri terhadap Pemahaman Konsep dan Hasil Belajar Mahasiswa Stikes Mega Rezky Makassar (Studi Pada Materi Pokok Titrasi Asam Basa). Chemistry Education Review (CER), 70-86.

Dewi, T. A. P., \& Sadjiarto, A. (2021). Pelaksanaan Pembelajaran Daring Pada Masa Pandemi Covid-19. Jurnal Basicedu, 5(4), 1909-1917.

Fakhriyah, F. (2014). Penerapan problem based learning dalam upaya mengembangkan kemampuan berpikir kritis mahasiswa. Jurnal Pendidikan IPA Indonesia, 3(1).

Kurniawan, D. C., Kuswandi, D., \& Husna, A. (2018). Pengembangan media video pembelajaran pada mata pelajaran IPA tentang sifat dan perubahan wujud benda kelas IV SDN Merjosari 5 Malang. JINOTEP (Jurnal Inovasi dan Teknologi Pembelajaran): Kajian dan Riset Dalam Teknologi Pembelajaran, 4(2), $119-125$.

Kurniasari, A., Pribowo, F. S. P., \& Putra, D. A. (2020). Analisis efektivitas pelaksanaan belajar dari rumah (BDR) selama pandemi Covid-19. Jurnal Review Pendidikan Dasar: Jurnal Kajian Pendidikan Dan Hasil Penelitian, 6(3), 246-253.

Novita, L., Sukmanasa, E., \& Pratama, M. Y. (2019). Penggunaan Media Pembelajaran Video terhadap Hasil Belajar Siswa SD. Indonesian Journal of Primary Education, 3(2), 64-72.

Nuryanti, L., Zubaidah, S., \& Diantoro, M. (2018). Analisis kemampuan berpikir kritis siswa SMP. Jurnal Pendidikan: Teori, Penelitian, dan Pengembangan, 3(2), 155-158..

Panggabean, D. D., \& Ramadhani, I. (2021). Pembuatan Media Video Pembelajaran Fisika SMA Dengan Whiteboard Animation. Media Sains Indonesia.

Prasetyo, T., Zulela, M. S., \& Fahrurrozi, F. (2021). Analisis Berpikir Kreatif Mahasiswa dalam Pembelajaran Daring Bahasa Indonesia. EDUKATIF: JURNAL ILMU PENDIDIKAN, 3(6), 3617-3628.

Purwanti, B. (2015). Pengembangan media video pembelajaran matematika dengan model assure. Jurnal Kebijakan dan Pengembangan Pendidikan, 3(1).

Syamsidah, S., Khery, Y., \& Mashami, R. A. (2018, September). Pengaruh Video Pembelajaran Kimia Terhadap Motivasi dan Hasil Belajar Kimia Siswa Kelas X. In Prosiding Seminar Nasional Lembaga Penelitian Dan Pendidikan (LPP) Mandala.

Van Harling, V. N. (2020). Analisis Hubungan Kedisiplinan Belajar Dari Rumah (Bdr) Dengan Prestasi Belajar Kimia Siswa Selama Masa Pandemi. Soscied, 3(2), 80-85.

Van Harling, V. N. (2021). Analisis Hubungan Tingkat Pemahaman Materi Perkuliahan Pengantar Ilmu Lingkungan dengan Menggunakan Google Classroom terhadap Hasil Belajar Mahasiswa. Jurnal Pendidikan Dan Kewirausahaan, 8(2), 155-164.

Wahyuni, S. (2015, September). Pengembangan bahan Ajar IPA untuk meningkatkan kemampuan berpikir kritis siswa SMP. In PROSIDING: Seminar Nasional Fisika Dan Pendidikan Fisika (Vol. 6, No. 6).

Wahyuningtyas, R., \& Sulasmono, B. S. (2020). Pentingnya media dalam pembelajaran guna meningkatkan hasil belajar di Sekolah Dasar. Edukatif: Jurnal Ilmu Pendidikan, 2(1), 23-27.Wisada, P. D., \& Sudarma, I. K. (2019). Pengembangan media video pembelajaran berorientasi pendidikan karakter. Journal of Education Technology, 3(3), 140-146.

Yunita, D., \& Wijayanti, A. (2017). Pengaruh Media Video Pembelajaran Terhadap Hasil Belajar IPA Ditinjau Dari Keaktifan Siswa. Sosiohumaniora: Jurnal Ilmiah Ilmu Sosial Dan Humaniora, 3(2).

Yusuf, A. M. (2016). Metode penelitian kuantitatif, kualitatif \& penelitian gabungan. Prenada Media. 
3338 Pengaruh Penggunaan Video Pembelajaran terhadap Kemampuan Berpikir Siswa pada Mata Pelajaran Kimia - Vina N. Van Harling

DOI: https://doi.org/10.31004/edukatif.v3i5.1215

Zubaidah, S. (2010, January). Berpikir Kritis: kemampuan berpikir tingkat tinggi yang dapat dikembangkan melalui pembelajaran sains. In Makalah Seminar Nasional Sains dengan Tema Optimalisasi Sains untuk memberdayakan Manusia. Pascasarjana Unesa (Vol. 16, pp. 1-14). 